\title{
The Nexus between Illicit Drug Trafficking and Terror: The PKK as an Example of Hybrid Transnational Threat
}

\author{
Haydar KARAMAN ${ }^{1}$
}

\begin{abstract}
All terrorist groups need finance to operate. It is a means for certain groups to accomplish their objectives; for others, it is the aims itself per se. Terrorist groups are therefore involved in different levels of organized crime. One of them is illicit drug trafficking, which has a nexus with organized crime and terrorist groups. This study aims to demonstrate a better understanding of the Kurdistan Workers' Party's (PKK) evolution into an organized criminal organization and its funding sources. From this point of view, the PKK is classified as a narco-terrorist organization with strong financial motives in this paper. As it will be analyzed on paper, its financial motivations frequently have weighed in the same level as its political motivation. It began to act as a hybrid organization through transnational offences, and it has steadily strengthened its criminal capabilities. Its members retain their deceptive political rhetoric to perform their illegal operations more easily. The organization can also be defined as a hybrid transnational organized crime group by UN standards, given the severity of its crimes and its criminal network spanning the Middle East, Turkey, and Europe.
\end{abstract}

Key Words: PKK, Terrorism, Narco-Terror, Illicit Drug Trafficking, Hybrid Organization

\section{Yasadış1 Uyuşturucu Ticareti İle Terör Arasındaki İrtibat: Sınıraşan Hibrit Tehdit Örneği Olarak PKK}

$\ddot{O} z$

Terörist grupların faaliyet gösterebilmeleri için finansmana ihtiyaçları vardır. Kimi gruplar için finansman hedeflerine ulaşması için bir araç iken; kimileri için de amacın bizatihi kendisidir. Terörist gruplar bu nedenle farklı organize suç düzeylerinde faaliyet göstermektedirler. Bunlardan biri de organize suç ve terörist gruplarla bağlantı noktası olan yasadışı uyuşturucu kaçakçılığıdır. Bu çalışma, ilgili bağlantıyı ortaya koyarak, Kürdistan İşçi Partisi (PKK) terör örgütünün söz konusu yasadışı finansal kaynaklar aracilığıyla gelişimini derinleştirmeyi amaçlamaktadır. Buradan hareketle, bu çalışmada PKK güçlü mali güdülere sahip bir narko-terör örgütü olarak sınıflandırılmaktadır. Çalışmada görüleceği üzere, örgütün finansal motivasyonlarının sıklıkla politik motivasyonları ile aynı derecede önem arz etmektedir. Her ne kadar örgüt siyasal söylemleri yasadışı işlemlerine paravan olarak kullansa da sınıraşan suçlar yoluyla melez bir örgüt olarak hareket etmeye başlayan örgüt zaman içinde suç işleme kapasitesini sürekli olarak güçlendirdi. Örgütün Orta Doğu, Türkiye ve Avrupa'daki suçları göz önüne alındığında, BM kriterlerine göre de uluslararası bir hibrit organize suç grubu olarak da sınıflandırılabilineceğini ortaya koymak çalışmanın bir amacıdır.

Anahtar Kelimeler: PKK, Terörizm, Narko-Terör, Yasadışı Uyuşturucu Kaçakçllı̆̆, Hibrit Organizasyon

Atıf İçin / Please Cite As:

Karaman, H. (2021). The nexus between illicit drug trafficking and terror: the PKK as an example of hybrid transnational threat. Manas Sosyal Araştrmalar Dergisi, 10(4), 2513-2527.

Geliş Tarihi / Received Date: 14.03.2021

Kabul Tarihi / Accepted Date: 24.05.2021

\footnotetext{
1 Öğretim Görevlisi Dr. - Kilis 7 Aralık Üniversitesi, İktisadi ve İdari Bilimler Fakültesi, haydar.karaman@kilis.edu.tr 


\section{Introduction}

Fighting against terrorism is not a new phenomenon. It has posed a threat to states' security and societies for ages. Millions of people have been targets of terrorist attacks; only in 2020, 13.826 people lost their lives worldwide (Vision of humanity, 2020) There have been dozens of attacks that have been mentioned with brutality in history. Even if terrorism was not started with the attack of $9 / 11$, this moment has become a turning point in the history of modern by its catastrophic outcomes. The $9 / 11$ terrorist attack not only exposed the inability of a state to defend itself; but also showed how threat was pluralized. This moment inherently leads the international community start sharing the responsibility to prevent future attacks. Politicians and scholars working to combat terrorism have consistently shown interest in identifying it and separating it from other criminal acts as part of this process. Criminal organizations, on the other hand, have evolved into "hybrid" entities in today's world as a result of their involvement in illegal business. These hybrid groups lead problems in combating terrorism due to their transnational crimes. The problem is no longer an event that can be prevented by the struggle of a single state but turns into a metaphor that can be prevented by the joint effort of the international community (Trapp, 2011).

The most important problem in terms of hybrid organizations and threats is seen in the combination of terrorism and drug trafficking. While these two elements constitute a threat to humanity on their own, they change their form by coming together and complicate the multiplication of the threat on the one hand and make the solution of the problem difficult. The combination of these two elements arose from the need to meet the financing needs of terrorism, as will be explained in the article. Because as can be seen, illegal drug use has become a major concern in people's everyday lives all over the world. As pointed out in UNDOC 2020 World Drug Report, "In 2018, an estimated 269 million people worldwide had used drugs at least once in the previous year (range: 166 million to 373 million). This corresponds to 5.4 per cent of the global population aged 15-64 (range: 3.3 to7.5 per cent), representing nearly 1 in every 19 people" (UNDOC, 2020). This figure was 30 per cent higher than 2009. Thousands of people have included the manufacture, trafficking, and selling of illicit drugs at all stages (UNDOC, 2020). The illicit drug trade is worth billions of dollars. The Rand Corporation Report stated that American spent nearly $\$ 150$ billion in 2016 to cannabis, cocaine, heroin and methamphetamine (Rand Corporation, 2019). The United Nations reports that the illegal drug trade is worth between $\$ 100$ billion and $\$ 1$ trillion dollars (UNDOC, 1998). Illegal organizations are attracted to this macroeconomic sector. Due to meet basic needs, not only organized crime but also terrorist organizations involve profitable illicit industry. Terrorist groups have formed alliances with illicit drug dealers, mostly for financial purposes, as they need funds to fight government forces.

The Partiya Karkeren Kurdistan (PKK) (hereinafter the PKK) takes advantage of the diaspora in Europe to form illicit drug trafficking. The militants had developed a network to raise funds for the PKK's political goals and terrorist attacks. The PKK is said to have a significant presence in the drug trafficking industry. For example, at its height in the terrorist groups' budget, the PKK was projected to get annual earnings of $\$ 86$ million - more than double that of Al-Qaeda (Roth, \& Sever, 2007, p. 6). PKK would have to be investigated for that purpose alone.

Therefore, the aim of this article is to look at the characteristics of terrorism in the context of international drug trafficking. The purpose of the article is to reveal how existing terrorist organizations emerged as a new entity by changing their form as a result of the financing of terrorism with drugs, and why this entity is more dangerous than classical structures. While expressing the importance of this new structure, emphasis will be placed on the effect of legal texts in terms of law. For a better analysis of terrorism, this article first examines the concept of terrorism in order to explain the topic under consideration. As a result, the different concepts of terrorism will be briefly discussed first.

After that, the article will look at the financial origins of terrorism. This chapter will cover two key topics: illegal activities of terrorist organization and government sponsorship on terrorism, especially drug trafficking. The PKK will then be scrutinized regarding these illegal activities and drug trafficking. The section first discusses the PKK and its history, while the second section explains the PKK's relationship with Europe. The last chapter will look at international conventions for fighting terrorism. The hybrid feature of this organization is also analyzed under a sub chapter. The last chapter will look at international conventions for fighting terrorism. The importance of the socioeconomic indicators will be emphasized. Finally, the conclusion part aims to clarify importance of the socioeconomic indicators on drug trafficking. 


\section{Defining of Terrorism}

\section{Perception of Scholars on Definition of Terrorism.}

Most scholars and policymakers believe that there will never be an acceptable, globally recognized concept of terrorism. Terrorism is an eristic concept that sparks debate; since "one man's terrorist is another man's freedom fighter" (Laqueur, 1987). In this point, Ex-Israel Prime Minister Benjamin Netanyahu (1986, p.18) emphasized that it is impossible to sanction the notion that one person's "criminal" is another's "freedom fighter". He stressed that "Freedom fighters don't blow up buses containing non-combatants; terrorist murderers do..." In contrast to Netenyahu, Ex-Syrian President Hafez el-Assad (Hafez el-Assad, the then president of Syria,) emphasized that "we have always opposed terrorism. But terrorism is one thing and a national struggle against occupation is another..." (Ganor, 2002, p. 292). It demonstrates that the countries or politicians have different perception on defining criteria of terrorism which lead a definitional paradox. Shanahan rephrased it as "globally workable definition of terrorism is an explicitly subjective one" (Shanahan, 2016, p. 103). Politicians find it incredibly difficult to come up with a neutral term.

At the very least, scholars have agreed that the point of terrorism is to "terrorize," with the act of doing so traditionally thought to be carried out by an organized power (Chaliand, \& Blin, 2007, p. 56). The perception on evaluation of meaning of "terrorism" has shifted considerably by intervention of academia. Whatever else the word may have meant, the term in holds two determinants, i.e. violence and intimidation (in other words fear). Despite conceptual vagueness, the dominant philosophical approach reflects that the term is understood as a type of violence. It could aim sadistic plan or intimidation to have impact on political, social, or religious circumstance. However, other factors are provided to define it. As Prabha (2000, p. 126-127) pointed out the "struggle in society between the haves and the have-nots" is the socioeconomic cause for terrorism. This argument is supported by Held (2008) who pointed that not achieving a just distribution of rights and commodity creates a problem on idea of fairness. Terrorism and violence can be useful tools for achieving goals. They can be used to help individuals overcome socio-economic difficulties or to achieve political advantage (Freytag, Krüger, Meierrieks, \& Schneider, 2011).

However, not all acts of violence can be classified as terrorism. Such acts of aggression, according to Prabha (2000, p. 130), cannot be classified as terrorism if they have no political implications. The violence is being used to achieve political objectives (Wilkinson, 2016). Another noteworthy argument is that terrorism's victims are civilians. As a result, terrorism is different from other forms of violence. Per Bauhn, who is the first author mentioned this criteria, pointed out that "The performance of violent acts, directed against one or more persons, intended by the performing agent to intimidate one or more persons and thereby to bring about one or more of the agent's political goals" (1989, p. 28).

As Di Filippo (2020, p. 16-17) argues that the potential content of a common notion of terrorism is revealed by examining the principles at stake. Terrorism is described as behavior that puts the lives of civilians in jeopardy. The aim to create an atmosphere of panic or excessive fear among the populace may lead to special legal treatment, leaving the perpetrators' real intentions or ultimate goals to the field of legal indifference. Of course, they may be political, or 'mixed,' or even ephemeral. What matters is that the reason for the special stigmatization is to defend a widely acknowledged value from an especially egregious type of assault. In this light, the long-debated issue of how freedom fighters are treated loses its meaning. The motive to spread fear should be derived primarily from the physical characteristics of the conduct (the methods employed).

Apart from agreeing that aggression and coercion are at the heart of terrorism, the meanings can vary in moral and ethical terms. Therefore, the article aims to keep this discussion limited in order not to distort the essence of the subject by expanding the scope of the article. Otherwise, ontological and epistemological challenges and limits of the term will come into question.

\section{Definition of Terrorism at Legal Texts}

Without examination of international network, the political position on terrorism will remain deficient. Terrorism is characterized by interactions between terrorist organizations. Terrorist attacks necessitate a large amount of ammunition and storage facilities, as well as a high level of danger if the action is conducted within the country's borders. Most of terrorist organizations receive support from abroad. The terrorism often entails illegal activity on both a local and international level. 
The organizations that define terrorism and related concepts demonstrate how they perceive a threat and what steps they will take to combat it. However, due to scope of The European Union, the EU addresses the most detailed concept of terrorism. In Article 1 of the "Framework Decision on Combating Terrorism", the EU defines terrorism for legal/official purposes (COE, 2002, 2002/475/JHA). Terrorist offenses are described as such criminal offenses from the following list, which is primarily comprised of serious crimes against civilian and property:

“(a) attacks upon a person's life which may cause deatb;

(b) attacks upon the physical integrity of a person;

(c) kidnapping or hostage taking;

(d) causing extensive destruction to a Government or public facility, a transport system, an infrastructure facility, including an information system, a fixed platform located on the continental shelf, a public place or private property likely to endanger human life or result in major economic loss;

(e) seizure of aircraft, ships or other means of public or goods transport;

(f) manufacture, possession, acquisition, transport, supply or use of weapons, explosives or of nuclear, biological or chemical weapons, as well as research into, and development of, biological and chemical weapons..." (COE, 2002, 2002/475/JHA)

The Resolution 1566 (UN, 2004) is the closest to an accurate definition of terrorism among the United Nations Security Council's Resolutions calling for action against terrorism. It includes three cumulative conditions:

"1. Acts, including against civilians, committed with the intention of causing death or seriousbodily injury, or the taking of hostages; and

2. Irrespective of whether motivated by considerations of a political, philosophical, ideological,racial, ethnic, religious, or other similar nature, also committed for the purpose of provokinga state of terror in the general public or in a group of persons or particular persons, intimidating a population, or compelling a government or an international organisation to door to abstain from doing any act; and

3. Such acts constituting offences within the scope of and as defined in the internationalconventions and protocols relating to terrorism." (UN, 2004, Res. 1566).

Also, the definition of terrorism in Turkish domestic law should be also taken into consideration. Article 1 of the Turkish Anti-Terror Law of 1991 regulates the definition that covers a wide range of terrorist acts:

"Terrorism is any kind of act done by one or more persons belonging to an organization with the aim of changing the characteristics of the Republic as specified in the Constitution, its political, legal, social, secular and economic system, damaging the indivisible unity of the State with its territory and nation, endangering the existence of the Turkish State and Republic, weakening or destroying or seizing the authority of the State, eliminating fundamental rights and freedoms, or damaging the internal and external security of the State, public order or general health by means of pressure, force and violence, terror, intimidation, oppression or threat. An organization for the purposes of this Law is constituted by two or more persons coming together for a common purpose. The term "organization" also includes formations, associations, armed associations, gangs or armed gangs as described in the Turkish Penal Code and in the provisions of special laws." (Turkish Anti-Terror Law, 1991).

As pointed at the Article of 220 of Turkish Penal code, the terror crime is defined through " $A$ person who makes propaganda for an organization in a manner which would legitimize or praise the terror organization's methods including force, violence or threats or in a manner which would incite use of these methods shall be sentenced to a penalty of imprisonment for a term of one to three years. If the said crime is committed through the press or broadcasting the penalty to be given shall be increased by half" (Turkish Criminal Code, 2004).

The definitional broadness of the terror term in Anti-Terror Law has been criticized. These criticisms arose after the 2006 changes to the anti-terror legislation. The 2006 amendments maintained the antiterror law's broad, ambiguous concepts of terror while expanding the number and nature of crimes that can be classified as terrorist offenses. In addition, the Anti-Terror Law lengthened the sentences for 
alleged terrorist acts, opens violations of fair trial rights up for dicussion, and paved the way for political crimes to be classified as terror crimes.

However, in the aftermath of the bombings in Ankara and Istanbul, as well as the Ditch (Hendek) Operations, both legislative and prosecutorial authorities have felt compelled to act and enforce special anti-terror legislation to combat these acts. These terrorist attacks, such as the 2016 Ankara Güvenpark, are clearly incompatible with human rights ideals, not least the right to life and inherent dignity of the human being to be used as a tool of another's ideology. As a result, the state has enacted a series of laws aimed at tightening both preventive and repressive measures in the "war on terror." There are several laws in place to punish and prevent terrorism. Following the terrorist attacks, a dramatic change in law enforcement was made to fight terrorism. Although, anti-terror law is efficient, now, by changing the current paradigm, the Turkish state aimed to eliminate not only the military side of terrorism but also its financial structure in the fight against terrorism.

\section{Financial Sources of Terrorism}

Idealism with specific philosophies form the basis of all terrorist organizations. If they advance, all groups must first and foremost gain a source of income. Terrorists must invest money in order to survive. Money has also been referred to as extremist organizations' "lifeblood" by some officials (Bush, 2002). These organizations would be unable to continue operating if they did not have access to financial resources and ammunition. However, how will they be able to collect funds? What are the sources of funding for terrorist organizations? The organization's funding comes from a wide range of sources, from state patronage to criminal activities (Passas, 2007, p. 31).

The management of a terrorist organization is a difficult task. Terrorist groups need as much cash as possible. Several conditions must be met in order to maintain propaganda (the development of multiple support networks; the establishment of facilities and funding to support training activities; and community contact), all of which necessitate a large sum of money. First and foremost, organizations must set aside money to attract new members. If they are operating outside of the States, they would need funds to establish new training camps as well as food and shelter for the militants. Furthermore, the organizations must obtain the appropriate equipment to carry out terrorist attacks (Gürel, 2015, p. 16-27). For their covert operations, they'll need false identity cards, other travel documents, and communication devices, for example. As can be seen, terrorist organizations need funds to maintain their life and resort for a variety of reasons. According to Interpol (1999), the main reasons are:

"- The new professional structure of organizations as a natural result of social, economic and technical developments,

- Enlargement of cadres,

- Lodging and living costs of members,

- Illegal and legal psychological propaganda activities, such as postings, booklets, Internet, publications, media broadcasting,

- Logistics (weapons and ammunition),

- Providing financial aid to the cadres, prisoners and their families" (Interpol, 1999).

If terrorist organizations are unable to procure ammunition and food by legitimate means in order to conceal their network, as a result, they are forced to engage in illicit practices such as "revolutionary taxes" and smuggling in order to survive. According to Interpol (1999), some terrorist groups' basic organized criminal activities to raise money include "- Contributions, Donations and Fees-Drug Trafficking, -Extortion,Revolutionary Tax,- Armed Robbery,- Kidnappings,- Legal companies,- Publications, legal and illegal”" (Interpol, 1999). One of the financing methods which are not listed at above differs from the others. State sponsorship does not provide only monetary funds, it covers a wide range of assistance options, including weapons, safe haven, funding, training, intelligence, and diplomatic cover, among others. Terrorist groups' preparation, recruitment, communications, transit, and logistics in support of particular attacks are supported by state sponsors. 


\section{State Sponsorship}

State financing is one of the most important sources of funding for terrorist organizations. In the case of state-sponsored terrorism, groups with broad conventional military capabilities would expect to recruit groups that have a better understanding of unconventional techniques or additional skills. Hizballah in Lebanon, for example, has established a unique range of terrorist capabilities in Bekaa Valley. Also, in the relationship between the state and the terrorists, the threat of violence is a major motivator. Although a state will claim that it will retaliate militarily for any perceived hostile state transgression, it can use the acts of its terror agents to signal a willingness to engage in tit-for-tat retaliation (Byman, \& Kreps, 2010, p. 9-12). In fact, however, any scheme of control that changes the relationship from discretionary to instrumental may hide the state's fingerprints on the terrorist organization, since the state supporting terrorism is attempting to function on the basis of plausible deniability. States apply terror sponsorship as a tactical tool of their foreign policies, and aim to curtail their levels of support.

Despite the fact that state support has declined dramatically since the fall of the Soviet Union, it still remains critical in sustaining terrorist activity. It was popular during the Cold War, when the USA and USSR sponsored groups all over the world (Masco, 2014). In addition to these two major actors of the cold war, many states also played an important role in financing terrorism. The main purpose here is to put the enemy states in a difficult situation both economically and politically. One of the states that implemented this most was Gaddafi's Libya at the time. Libya also provided safe houses and financial assistance to a number of organizations in Europe, including the Irish Republican Army (IRA) (Haverty, 2018), the Palestine Liberation Organization (PLO) (Vittori, 2011), Euskadi Ta Askatasuna (ETA) (Abadie and Gardeazabal, 2003) and Rote Armee Fraktion (RAF) (Sonmez, 2019). Terrorist organizations benefit from state funding since it has the ability to pay vast amounts of money and provide terrorists with safe havens for years. Terrorists, on the other hand, suffer from state patronage in terms of control and reliability. For starters, a state may exert control over an organization's operations, implying that they are operating in the state's best interests (Freeman, 2011, p. 466).

However, terrorist groups have been able to reduce their dependence on geographic proximity of members due to communications revolution after the Cold War. Terrorist groups such as al Qaeda have built their own revenue sources through smuggling and other forms of illegal trade (primarily drug trafficking), as well as through deceptive charity schemes. Both the advantage of using their own organizational power and the magnitude of their financial returns are attractive compared to others. This is illegal drug trafficking. It is precisely for this reason that the article wants to reveal the link between drug trafficking and terrorism, and to reveal the PKK's transformation into a hybrid structure, taking into account the relational network at this point. Large-scale terrorist organizations engage in organized criminal activity for these purposes. Terrorist financing may come from a variety of places including illicit drug trafficking.

\section{Drug Trafficking}

Terrorists can smuggle almost anything to finance their operations, including drugs and individuals, making smuggling more lucrative than other illegal activities. Prices are controlled from the point of cultivation to the point of distribution. Berthiaume and others (1997, p. 17) pointed out that, in most situations, these groups do not participate in drug use during the early stages of their conflict. However, as the number of cadres and operations grows at the expansion process, they are forced to become involved in drug trafficking. Their expansion progress is determined by the organization's funding requirements.

As a result, the connection between terrorism and illegal drug trafficking has received a great deal of attention, and the word "narco-terrorists" has been coined (Davids, 2002). The drug trade is a source of income for some of the most well-known terrorist organizations. The FARC (Otis, 2014), a Colombian terrorist group, and the PKK are two of the most well-known terrorist organizations for their roles in the drug trade; they may be classified as narco-terrorist organizations (Picarelli, \& Shelley 2002, p. 313). These terrorist are more politically motivated fighters who have been involved in drug trafficking; their agendas are heavily influenced. Their aim is to create economic instability and achieve a more equal distribution of income. They would be able to protect peasants from the government. As a result, they could be trading drugs for weapons with drug traffickers (Oscapella, 1998, p. 17). 


\section{Monetary Funds of the PKK}

This chapter makes extensive use of information on the PKK, which Britain's MI5 has identified as one of the world's "bloodiest terrorist organizations." Therefore, while the paper looks at the wider security ramifications of Turkey's illegal drug trade, it interests transnational nature of crime. Since, Turkey, as a strategic location, is a route for massive flows of narcotics. Thus, this paper aims to draw attention to their involvement in illegal activities, especially drug trafficking between Turkey and Europe.

To begin, I would like to give a very brief historical and theoretical background on the PKK, which is necessary to better understand its actions. The PKK's philosophical basis was based on Marxist-Leninist philosophy and ideology. Abdullah Ocalan, the founder of the PKK, established the PKK at a meeting in Diyarbakir on November 27, 1978 (Unal, 2012). Despite its Marxist-Leninist roots, it has always tried to hide behind Kurdish nationalism; Marxism established its true ideology. According to Mincheva and Gurr (2008, p. 4), from its inception the PKK was made up of both ethnic Turks and Kurds, refusing any common interest based on ethnic identity. The organization then aspired to long-term territorial goals, such as freedom for 'Kurdistan.' In the years that followed, the PKK justified its acts of terrorism by claiming to be defending the Kurdish identity movement and promoting the Kurdish struggle for selfdetermination.

Since its foundation in 1984, the PKK has killed over 30,000 civilians and security forces, according to Turkish authorities (Masullo, \& O'connor, 2020, p. 77-99). It has also harmed the Turkish economy. In May 2002, the EU added the PKK to its list of terrorist organizations, and the PKK was added to the US (the United States of America) list of international terrorist organizations in 2004.

\section{State Sponsorship of PKK}

When the paper looks closely, under normal circumstances, without allies, the PKK would not have been able to wage a long and drawn-out war against Turkey. Due to the clandestine existence of state funding, exact figures of states sponsoring terrorist organizations are difficult to come by. As it will seen below, the PKK is a terrorist group that was heavily subsidized by the government until the early 2000s. While the PKK's main backers have been Turkey's neighbours, such as Syria, Iraq and Iran, who have provided safe haven, funding, and arms to the terrorist group, the PKK has had sponsors from all over the world. Many of Turkey's neighbours have previously provided money, ammunition, and training to the PKK, as well as safe havens and political support. For example, as Orhan $(2014$, p.31) pointed out the PKK received armed combat training in neighbouring countries, primarily in Syria-controlled Lebanon's Bekaa Valley, where many terrorists lived in the early 1980s.

Furthermore, the PKK has allegedly taken advantage of a special status given by Greece and Cyprus, according to Turkish authorities. Ocalan was apprehended in the Greek Embassy in Kenya in 1999, according to one piece of evidence. Ocalan was in possession of a Greek Cypriot government-issued passport. As a result, the Turkish authorities were led to believe that Greece was funding the PKK. Furthermore, Ocalan made a public statement about Greece, and acknowledged that "Greece has for years supported the PKK movement. They even gave us arms and rockets..." (CNN, 1999).

Furthermore, while state funding has always been a convenient and lucrative financial outlet for terrorist organization such as the PKK, state sponsors may be able to limit terrorist acts by pressuring groups to behave in accordance with state interests. However, since terrorist groups have been used by several nations, this path, limitation, is not chosen. In both economic and political terms, it is a less expensive alternative to direct conflict with the enemy. Despite, the PKK has been tolerated almost as a legal entity when it comes to taking advantage of foreign opportunities.

\section{Illegal Drug Trafficking and the PKK}

The PKK lost state help after Ocalan was captured by Turkey. As a result of its financial difficulties, the organization morphed from a traditional terrorist organization into a criminal gang that funds itself. Questions have been raised at this stage. What sources of funding did the PKK use to finance its 'revolutionary' and terrorist activities? What is the PKK's primary source of funding?

The PKK's most profitable industry has proved to be the drug trade. Turkey's favorable geographical position at the crossroads between Asia and Europe is taken into account. Turkey is also one of the major transit points for heroin from the Middle East into Europe. A significant amount of drugs are transported 
via Turkey on their way to Europe via the Balkan road. The PKK's drug trade involvement is largely motivated by the substantial income that can be gained from illicit drug trafficking (Ministry of Foreign Affair of Turkey, 2012). TADOC reports that a kilogram of heroin can be purchased from the manufacturer for $\$ 1,000-2,000$, and the price can grow to $\$ 200,000$ on the streets of Europe (Sahin, 2001, p. 41). The PKK's drug trade involvement is largely motivated by the substantial income that can be gained from illicit drug trafficking.

The PKK is active in every aspect of the illegal drug trade, from manufacturing to storage to marketing (Ministry of Foreign Affair of Turkey, 2021). The PKK is a drug distribution organization that also cultivates cannabis. Huge cannabis farms were found near a PKK camp in the Bahara Valley, according to Turkish police, and the drugs seized totaled more than 4.5 tons (Mincheva, \& Gurr 2008, p.19). Between 1984 and 1993, the Turkish National Police's Department of Anti-Smuggling and Organized Crime arrested 298 people connected to PKK drug sales (Roth and Sever, 2007, p.907). Furthermore, between 1984 and 1993, the National Central Bureau of Interpol in Turkey prosecuted 503 people connected to the PKK for drug trafficking with Europe's drug network (Roth and Sever, 2007, p.907). In his 2003 trial testimony, Ocalan replied to the judge's query about whether the PKK was involved in drug trafficking, confirming the authorities' claim as:

\section{"... the resource of our money was drug trafficking. The PKK and Apo (Abdullab Ocalan) have always gotten a big share from the drug trafficking in Turkey on the drug route of Middle East to Europe. We bought arms with the money gained from this..." (KOM 2003).}

In the 1990s, Interpol looked into the PKK's narcotics trafficking activities. With the support of many Kurdish clans, the organization was able to carry out its operations. To traffic drugs, the PKK didn't need a well-organized structure; it already existed among Kurdish Diaspora migrants in Europe (White, 2005). The PKK was primarily based in the Netherlands, France, Belgium, United Kingdom and Germany with links to Kurdish migrants in both countries (Krueger, \& Pischke, 1997). In 2003, the Turkish Grand National Assembly's Human Rights Commission interrogated Semdin Sakik, the head of the Sakik Clan and a former PKK leader, in Diyarbakir Prison. In the case of European drug trafficking, he confirmed the PKK's involvement to the international drug trade.

Furthermore, the PKK involves in the European drug trade, particularly in France and Germany, with clandestine criminal organizations, and not only employs Kurdish migrants. According to French law enforcement, the PKK is responsible for 80 percent of heroin in Paris (Cilluffo, 2000). In addition, the British National Service of Criminal Intelligence estimates that Turkish-Kurdish gangs smuggle in most of heroin in the UK (Sozer, \& Yllmaz 2019, p. 197) (BBC, 2002). Furthermore, Gunter Becktein, the Bavarian Minister of the Interior, claimed that the PKK controlled the European drug market. He went on to say that the PKK's overall involvement in European drug trafficking has ranged from $40 \%$ to nearly 80\% (Turkish Daily Cumhuriyet, 1995). The PKK and arrested drug syndicate/cartel members also exposed the PKK's involvement in the illicit drug trade during police operations (Clark, 2008). In his trial testimony, Selim Curkkaya, a former financial relations officer for the PKK in Europe, admitted to making a lot of money from drug deals (Roth and Sever, 2008). He also said that the money was transferred to the PKK by Kurdish drug dealers who are PKK supporters via Selim Curkkaya.

German authorities detained 15 Kurdish people for possessing 1.6 kilograms of heroin in 1993, demonstrating the PKK's influence on Europe's streets. Surprisingly, they were both former prisoners accused of armed attacks and PKK members in Turkey (TADOC, 1998a). In addition, Interpol concluded more than 100 cases related to the PKK, which reported that 15 tons of different types of drug were seized in Europe. As a result of their extensive involvement in the European drug trade, the PKK has evolved into not only a Turkish crime organization but also a European crime organization. From the beginning of Syrian Civil War, the PKK's Syrian section the PYD has used the Syrian Route for illicit drug trafficking to Europe (Tetik, \& Görücü, 2019, p. 12-19). As Pointed out in 2019 report, while the amount of heroin seized in 28 member countries of the European Union has been recorded as an annual average of 4.3 tons recently (2014-2016), Turkey, in this period was more quantity of heroin seized from all European countries. As seen 2019 statics, the figures demonstrate how combatting against trafficking is important for Turkey: 
Table 1. Uyusturucu Raporu-Drug Report (EGM, 2019)

\begin{tabular}{lc}
\hline Operation Number & 448 \\
Suspect Number & 1442 \\
Heroin/kg & 63790 \\
Opium/kg & 5433 \\
Morphine/kg & 71,2 \\
Cocaine/kg & 4315 \\
Ectasy/pc & 9100 \\
Acid anhydride/lt & 137.447 \\
Cannabis/rt & 88.000 .000 \\
\hline
\end{tabular}

(http://www.narkotik.pol.tr/kurumlar/narkotik.pol.tr/TUBİM/Ulusal\%20Yayınlar/.)

Turkey experienced a decline in the amount of catch in the 2014-2016 periods (from 5.6 tons to 12.8 tons) (EGM, 2019). For this reason, it is declared by Turkish authorities as "The PKK is a clear example of the interconnected nature of terrorism and transnational organized crime" (Ministry of Foreign Affairs of Turkey, 2012). This issue was also reported by the Minister of Interior Süleyman Soylu as "The revenue PKK earns from drugs annually is \$1.5 billion." (Anadolu Agency, 2019).

\section{Transformation of the PKK to a Hybrid Organisation}

Rather than a simplistic black-or-white categorization of warfare types, the term "hybrid" ${ }^{2}$ is first identified through warfare that poses a multimodal or multivariant threat. The threat is blended with different combinations of assault (Hammes, 2005). According to this hybrid warfare, the enemy employs unique combinational threats, including criminal methods, specifically designed to State's vulnerabilities. As Mike Evans (2003, p. 136) indicated that "the possibility of continuous sporadic armed conflict, its engagements blurred together in time and space, waged on several levels by a large array of national and sub-national forces means that war is likely to transcend neat divisions into distinct categories." As Erendor and Tamer (2017) pointed out terrorist organization aims to damage states facilities, such as electrical power through cyber terrorist activities, which complex modes of war was a subtext to National Defence Strategy (2006) and took part in NATO Capstone Concept (IMSM-0292-2010). As a result, it was confirmed that potential threats would progressively be defined by a hybrid mix of conventional and irregular strategies. Terrorist attacks (including indiscriminate abuse and coercion) and illegal acts are examples of these techniques.

These multimodal operations may be carried out by different units or even the same unit, but they are usually coordinated from a single point for maximum physical and psychological benefit. Thus, threats will not be in separate boxes such in conventional war, but will be more complex threat future may be ahead. As it is increasingly seen that blended different methods or modes of warfare. This hybrid threats/challenges, however, are not only subject of single State. Because of transnational nature of terrorist and criminal organizations, future conflicts will feature a more diverse array of alternate mechanisms and tactics, as we were witnessed in the battle between Israel and Hizbullah, in 2006 (Peters, 2006, p.39). It emphasizes the true granularity or width of the potential conflict continuum.

However, in time, hybrid threats concept evolved and defined through new conceptualization as "any adversary that simultaneously and adaptively employs a fused mix of conventional weapons, irregular tactics, terrorism, and criminal behavior in the battlespace to obtain their political objectives" (Hoffman, 2010, p. 443). The main reason of this evolution is increasing need to generating funding of organizational network for terrorist groups. These groups/organization are "bighly adaptive and show a great ability to learn and adjust their behaviors based on lessons learned and changes in the operational environment." (Center and Command, 2011). In brief, they can avail themselves of all methods and means to accomplish their goals. Global terrorism uses different methods such as cyber-crime which is labeled by NATO (Erendor, 2016) as 'Hybrid Threats', as threats "posed by adversaries, with the ability to simultaneously employ conventional and non-conventional means adaptively in pursuit of their objectives" (New NATO, 2010). The terror organizations somehow use new threats against States.

\footnotetext{
2 Note: The word of hybrid defined in Etymology Dictionary as "c. 1600, offspring of plants or animals of different variety or species, from Latin hybrida, variant of ibrida mongrel, specifically offspring of a tame sow and a wild boar, of unknown origin but probably from Greek and somehow related to hubris. A rare word before the general sense anything a product of two heterogeneous things emerged c. 1850. The adjective is attested from 1716. As a noun meaning automobile powered by an engine that uses both electricity and gasoline 2002, short for hybrid vehicle, etc." Erişim Adresi: https://www.etymonline.com/word/hybrid.
} 
This pressure on terrorist group's finance led them to transform their organizations by increasing criminal capabilities in order to generate revenue. The U.S. intelligence analyst Chris Dishman (2001, p. 44) underlined that this situation leads those groups to ally with organized crime groups or transform themself as hybrid organization which executes illicit cross-border activities. This organized crime role has a potential metamorphosis to be raison d'etre. Over time, this metamorphosis becomes the structure itself, encapsulates it and dampens the initial ideology by destroying it. The organizational capability becomes paramount and "legitimated" element by which to sustain the criminal organization. This nexus between terrorism and organized crime, and their operational overlaps, are enabled to generate funding. By potential long-term multi task function, hybrid groups would gain from combined operations (Anderson, 2000). Due to above-mentioned overlap, as Angela Veng Mei Leong (2007) notes that we cannot identify neither organized crime nor terrorism as a homogenous term. Picarelli and Shelley (2002, p. 305-318) also added diversity does not exist. In this discussion, Björnehed (2004, p. 305-324) employs Makarenko's (2004) theoretical model of terrorism, drug trafficking and other crimes identifies intersections between the two (or more) phenomena and ends with drugs trafficking as a terrorism-related phenomenon. Moreover, Terrorist groups will become more dependent on transnational organized crime in the future, according to Lowe (2006)'s report.

As parallel with PKK case, terrorist organization uses different transnational criminal offences such racketeering. Rudner analyzed Hizbullah's financial apparatus. He emphasized that the group launders illicit funds obtained through drug and human trafficking through countries' formal and informal banking systems (Rudner, 2010, p. 700-715). Horgan and Taylor (2003) also observed similar situation on the money laundering of the Provisional Irish Republican Army. While these organization carry out to engage into organized crime, raison d'être shifts from political to economic goals. Yet, it causes a transformation not only methods, but also their motives as well. The overlapping materialized, when crime and terror groups begin to appropriate each other's activities, as Makarenko (2004, p.128) demonstrates. Both types of groups inevitably unite into one group as their different motivations become muddled. All acts are legitimized by ideological cover. It becomes impossible to categorize them as solely a terrorist or an organized criminal organization. Due to inevitable nexus of different crimes, not only the FARC, the Hizbullah, the Provisional IRA, but also the PKK is transformed to hybrid organization.

\section{The Fight against Terrorism's Financial Sources}

Through can the impact of economic and political sanctions, societies around the world will continue to fight terrorism effectively. In the fight against terrorism, strengthening and maintaining multilateral cooperation is critical. When Turkish authorities ordered that MED TV's accounts be frozen, Belgian police launched an investigation as an example of international cooperation. The MED TV, PKK's screen company, is a front for the PKK. Also, it was used to launder funds for the organization. In the case of money laundering, Belgian police discovered a connection between illicit drug trafficking and media broadcasting (Ozkan, 2016, p. 315-322). The Belgian government shut down MED TV during the Belgian police operation (Operation Sputnik) because of its involvement in illegal activities (Roth, \& Sever, 2007, p. 906).

The international compliance mechanism put in place under previous multilateral treaty agreements has proven ineffective in monitoring and suppressing this trade. The United Nations Convention against Illicit Traffic in Narcotic Drugs and Psychotropic Substances was enacted in 1988 as a result of this (UN, 1988). Its aim is to create a new international legal framework to tackle international drug trafficking. It requires party states to work together to take broad steps to combat illegal trafficking across national borders, as well as to pass and implement strict anti-drug laws within their own jurisdictions (UN, 1988):

- The production, manufacture, distribution or sale of any narcotic drug or psychotropic substance;

- The possession or purchase of any narcotic drug or psychotropic substance for the purpose of illicit trafficking;

- The manufacture, transport or distribution of materials, equipment and substances for the purpose of illicit cultivation, production or manufacture of narcotic drugs or psychotropic substances;

- The organization, management or financing of any of the foregoing offenses. 
Combating terrorism's financial outlets is critical to winning the war on terror. As a result, the Financial Action Task Force (FATF) was created (Alexander, 2001). This specialized organization is in charge of preventing the laundering of profits from illegal activities, freezing those accounts, and prosecuting those who aid in the financing of terrorist organizations. The FATF demands that states make funding of terrorist acts and terrorist organizations illegal. States should make certain that certain crimes are labeled as money laundering. Furthermore, Article 8 of the United Nations International Convention for the Suppression of Terrorist Financing, which was adopted in 1999, emphasized that countries have a primary duty to identify, track, freeze, seize, and confiscate any terrorist group that assists in the deprivation of funds to terrorists (UN, 1999). The UN Convention of 1999, on the other hand, emphasized the importance of the provisions of reciprocal legal assistance and extradition. This is a critical point in fighting against terrorism.

As a result, Turkey's global strategy to combat illicit drug trafficking and transnational offence is based on the belief that the issue can be solved by robust international cooperation, data sharing, and collaboration. In light of this, all relevant UN drug control treaties have been signed and ratified by the Turkish government. The war against the PKK and its funding sources has been supported by this cooperative effort.

\section{Conclusion}

The religious and ethnic identity groups frequently have the ability to transform their entities to the hybrid form which poses serious security risks. As Mincheva and Gurr (2008) pointed out transnational terrorist organizations can create criminal enterprises in order to obtain funds and arms. The research contains a significant amount of criminal evidence and extracts from actual events, implying a connection between illegal drugs and terrorist groups. There are distinctions made between drugs and terrorism in this section. This is mostly due to the essence of the organizations' illicit business and operations: the business is illegal, and the activities are hidden from one criminal group to the next. As a result, besides the narcoterrorist organization conception, we can call that the PKK is not only a terrorist organization, but also a hybrid criminal group.

As previously stated, there is sufficient evidence to support the PKK's drug trafficking activities. Despite their simplistic agendas, terrorist groups either provide safe houses for drug manufacturing or partner with drug traffickers in the battle against government forces, as this case study illustrates. Regardless of what else is said, drug trafficking is a highly lucrative industry. Drug trafficking is a seductive solution for criminal organizations that are still looking for new sources of income. This approach also has a problem with political and moral acceptability. They, however, justify their role in the illicit drug trade. They assert that in the fight against the State, every tactic is appropriate.

The PKK is said to be involved in all stages of drug trafficking, including production and marketing, according to Turkish authorities, at this time (EGM, 2018). Members are also actively involved in illicit drug sales, not only in Turkey but across Europe. As a result, the PKK, as a hybrid organization, was involved transnational and foreign crimes. The organization commits offences not only as a terrorist organization, but also as a criminal syndicate. The PKK's international nature necessitates mutual cooperation in the fight against financial sources. And in this manner may we foresee a peaceful environment and future for next generations.

\section{Ethical Declaration}

In the writing process of the study titled "The Nexus between Illicit Drug Trafficking and Terror: The PKK as an Example of Hybrid Transnational Threat", there were followed the scientific, ethical and the citation rules; was not made any falsification on the collected data and this study was not sent to any other academic media for evaluation. Since the document is examined in this study, there is no requirement for an ethics committee decision.

\section{References}

Abadie, A. \& Gardeazabal, J. (2003). The economic cost of conflict: A case study of the Basque country. The American Economic Review, 93, 113-132. Erişim adresi: https://economics.mit.edu/files/11870

Alexander, K. (2001). The international anti-money-laundering regime: the role of the financial action task force. Journal of Money Laundering Control, 3(4), 231-248. doi: 10.1108/eb027276 
Anadolu Agency. (2019). PKK earns \$1.5b annually from drugs: Turkish minister. Erişim adresi: https://www.aa.com.tr/en/todays-headlines/pkk-earns-15b-annually-from-drugs-turkish-minister/1376112.

Anderson, J. H. (2000). International terrorism and crime: trends and linkages. William R. Nelson Institute for Public Affairs, Virginia: James Madison University.

Orhan, M. (2014). Transborder violence: the PKK in Turkey, Syria and Iraq. Dynamics of Asymmetric Conflict, 7(1), 3048. doi: 10.1080/17467586.2014.909946

Bauhn, P. (1989). Ethical aspects of political terrorism: the sacrificing of the innocent. Lund: Lund University Press.

BBC (2002). 'Mafia' threatens UK Turks and Kurds. Erişim adresi: http://news.bbc.co.uk/2/hi/uk_news/2284780.stm

Björnehed, E. (2004). Narco-terrorism: the merger of the war on drugs and the war on terror. Global Crime, 6(3-4), 305-324. doi: 10.1080/17440570500273440

Byman, D., \& Kreps, S. E. (2010). Agents of destruction? Applying principal-agent analysis to state-sponsored terrorism. International Studies Perspectives, 11(1), 1-18. $\quad$ Erişim https://www.jstor.org/stable/pdf/44218618.pdf?refreqid=excelsior\%3A059786d8f8ece051b35a3306923b293d

Bush, G. W. (2002). Remarks by the president at United Nations financing for development conference, Cintermex Convention Center, Monterrey, Mexico, March $22 . \quad$ Erişim adresi: http://www.whitehouse.gov/news/relaeses/2002/03/20020322-I.html.

Center, J. I. W. \& Command, U. J. F. (2011). Irregular adversaries and hybrid threats. An assessment, July 12, Erişim adresi: https://publicintelligence.net/u-s-joint-irregular-warfare-center-irregular-adversaries-and-hybrid-threats2011-assessment/

Chaliand, G. \& Blin, A. (2007). Zealots and Assassins. In Chaliand, G. \& Blin, A. (Eds). The history of terrorism: from antiquity to al-Qaeda (pp. 55-78). London: University of California Press.

Cilluffo, F. (2000). The threat posed from the convergence of organized crime, drug trafficking, and terrorism. Testimony of the Deputy Director, Global Organized Crime Program, Director, Counterterrorism Task Force, Centre for Strategic and International Studies, Washington (DC) to the US House Committee on the Judiciary Subcommittee on Crime. Erişim adresi: http://commdocs.house.gov/committees/judiciary/hju68324.000/hju68324_0f.htm

Clark, P. (2008). Reassessing US national security strategy: the Kurdistan worker's party (PKK). Carlisle Barracks Pa: Army War Coll.

CNN (1999). Ocalan reportedly implicates Greeks in supporting PKK. Erişim adresi: http://edition.cnn.com/WORLD/europe/9902/22/kurds.02/.

Crenshaw, M. (1981). The cause of terrorism. Comparative Politics, 13(4), 379-399. doi: 10.2307/421717

Davids, D. (2002). Narco terrorism: A unified strategy to fight a growing terrorist menace. Amsterdam: Brill Nijhoff.

Deeb, M. J. (1988). Libya. (Review of the book Qaddafi and the Libyan revolution, by D. Blundy \& A. Lycett.). Middle East Journal, 42(1), 115-116.

Di Filippo, M. (2020). The definition (s) of terrorism in international law. In Research Handbook on International Law and Terrorism. Edward Elgar Publishing.

Dishman, C. (2001). Terrorism, crime, and transformation. Studies in Conflict and Terrorism, 24(1), 43-58. doi: $10.1080 / 10576100118878$

Emniyet Genel Müdürlüğü (2018). 2018 Mayıs raporu. Kaçakçıllk ve organize suçlarla mücadele Ankara. Erişim adresi: $\quad$ https://www.egm.gov.tr/kurumlar/egm.gov.tr/IcSite/kom/YAYINLARIMIZ/TÜRKÇE/2018RAPORU-TURKCE.pdf

Emniyet Genel Müdürlüğü (2003). 2003 Mayıs raporu. Kaçakçllık ve organize suçlarla mücadele raporu. Ankara: KOM Daire Baskanligi Yayinlari. Erişim adresi: https://www.egm.gov.tr/kom/raporlarimiz

Erendor, M. E. (2016). Risk toplumu ve refleksif modernleşme çerçevesinde siber terörizm: tanımlama ve tipoloji

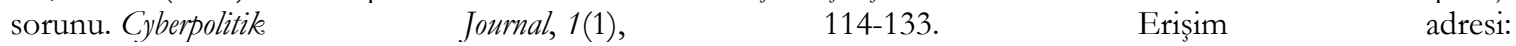
http://cyberpolitikjournal.org/index.php/main/article/download/94/92

Erendor, M. E., \& Tamer, G. (2017). The new face of the war: cyber warfare. Cyberpolitik Journal, 2(3), 53-70. Erişim adresi: https://dergipark.org.tr/tr/download/article-file/418745

European Union (Council of the European Union. (2002). Council framework decision 2002/475 on combating terrorism, 13 June 2002, 2002/475/JHA. Erişim adresi: https://www.refworld.org/docid/3f5342994.html.

Evans, M. (2003). From Kadesh to Kandahar: military theory and the future of war. Naval War College Review, 56(3), 132-150. Erişim adresi: https://digital-commons.usnwc.edu/cgi/viewcontent.coii?article=2247\&context=nwcreview

Freeman, M. (2011). The sources of terrorist financing: theory and typology. Studies in Conflict \& Terrorism, 34(6), 461475. doi: 10.1080/1057610X.2011.571193

Freytag, A., Krüger, J. J., Meierrieks, D., \& Schneider, F. (2011). The origins of terrorism: Cross-country estimates of socio-economic determinants of terrorism. European Journal of Political Economy, 27, S5-S16. Erişim adresi: https://www.econstor.eu/bitstream/10419/119352/1/diw_econsec0027.pdf

Ganor, B. (2002). Defining terrorism: Is one man's terrorist another man's freedom fighter?. Police Practice Research: An International Journal, 3(4), 287-304. doi: 10.1080/1561426022000032060

Gürel, S. (2015). Terör ve terör örgütlerinin finans kaynakları. Uluslararası Yönetim ve Sosyal Araştırmalar Dergisi, 2(4), 16-27. Erişim adresi: https://dergipark.org.tr/en/download/article-file/492810

Hammes, T.X. (2005). Insurgency: modern warfare evolves into a fourth generation. Strategic Forum, No. 214, Washington, DC: National Defense University Press. 
Haverty Jr, D. J. (2018). 'Positive neutrality': revisiting Libyan support of the provisional IRA in the 1980s. Global Histories: A Student Journal, 4(1), 46-65. doi: 10.17169/GHSJ.2018.166

Held, V. (2008). How terrorism is wrong: morality and political violence. Oxford: Oxford University Press.

Hoffman, F. G. (2010). 'Hybrid threats': neither omnipotent nor unbeatable. Orbis, 54(3), 441-455. doi: 10.1016/j.orbis.2010.04.009

Horgan, J., \& Taylor, M. (2003). Playing the 'green card'-financing the provisional IRA: part 2. Terrorism and Political Violence, 15(2), 1-60. doi: 10.1080/09546550312331293027

Interpol General Secretariate. (1999). Financing of terrorism. Paper presented at International Terrorism Symposium. Colombo, Sri Lanka.

Klepak, H.P., Aureano, G. R., \& Canadian Foundation for the Americas (1997). Hemispheric addiction: Canada and drug trafficking in the Americas. Canadian Foundation for the Americas: Foundation Canadienne Pour Les Amériques.

Krueger A.B. \& Pischke J.S. (1997). A statistical analysis of crime against foreigners in united Germany. The Journal of Human Resources. 32(1), 182-209. Erişim adresi: https://www.jstor.org/stable/pdf/146245.pdf

Laqueur, W. (1987). The age of terrorism. Toronto: Little, Brown and Company.

Leong, A. V. M. (2007). Chasing dirty money: domestic and international measures against money laundering. Journal of Money Laundering Control. 10(2), 140-156. doi: 10.1108/13685200710746857

Lowe, P. (2006). Counterfeiting: links to organised crime and terrorist funding. Journal of Financial Crime, 13(2), 255257. doi: $10.1108 / 13590790610660944$

Makarenko, T. (2004). The crime-terror continuum: tracing the interplay between transnational organised crime and terrorism. Global Crime, 6(1), 129-145. doi: 10.1080/1744057042000297025

Masco, J. (2014). The theater of operations: national security affect from the cold war to the war on Terror. Durham: Duke University Press.

Masullo, J., \& O'connor, F. (2020). PKK violence against civilians: beyond the individual, understanding collective targeting. Terrorism and Political Violence, 32(1), 77-99. doi: 10.1080/09546553.2017.1347874

Miklaucic, M., Aaronson, M., Diessen, S., De Kermabon, Y., \& Long, M. B. (2011). NATO countering the hybrid threat. PRISM, No. 4, 111-124. Erişim adresi: https://cco.ndu.edu/Portals/96/Documents/prism/prism_24/Prism_111-124_Aaronson-Diessen.pdf

Mincheva, L. \& Gurr, T. R. (2008). Unholy alliances iii: communal militants and criminal networks in the Middle East, with a case study of the Kurdistan workers party (PKK). In Annual Meeting of the International Studies Association, Panel on Ethnicity, Identity and Militancy in the Middle East, San Francisco.

Ministry of Foreign Affair of Turkey. (2012). No: 221, 19 September 2012, Press release regarding operations carried out in Denmark against the PKK terrorist organization, Erişim adresi: http://www.mfa.gov.tr/no_-221_-19-september2012_-press-release-regarding-operations-carried-out-in-denmark-against-the-pkk-terrorist-organization.en.mfa

Netanyahu, B. (1986). Terrorism; how the west can win. New York: Avon Books.

Online Etymology Dictionary (2021). The word of hybrid. Erişim adresi: https://www.etymonline.com/word/hybrid

Oscapella, E. (1998). The relationship between illegal drugs and firearms: a literature review. Department of Justice Canada, Policy Sector, Toronto: Canadian Firearms Centre.

Otis, J. (2014). The FARC and Colombia's illegal drug trade. Washington: Wilson Center.

Ozkan, O. (2016). Money-laundering activities of the PKK. New York: Springer.

Passas, N. (2007). Terrorism financing mechanisms and policy dilemmas. In Giraldo, J., \& Trinkunas, H. (eds)., Terrorist financing and state responses: a comparative perspective (pp. 21-38). Stanford, CA: Stanford University Press.

Peters, R. (2006). Lessons from Lebanon: the new model terrorist army. Armed Forces Journal, 114(3), 39-53. Erişim adresi: http://armedforcesjournal.com/lessons-from-lebanon/

Picarelli, J. \& Shelley, L. (2002). Methods not motives: implications of the convergence of international organised crime and terrorism. Police Practice and Research, 3(4), 305-318. doi: 10.1080/1561426022000032079

Prabha, K. (2000). Defining terrorism. Strategic Analysis, 24(1), 125-135. doi: 10.1080/09700160008455199

Rand Corporation (2019). Americans' spending on illicit drugs nears $\$ 150$ billion annually; appears to rival what is spent on alcohol. Erişim adresi: https://www.rand.org/news/press/2019/08/20.html.

Roth, M. P. \& Sever, M. (2007). The Kurdish workers party (PKK) as criminal syndicate: funding terrorism through organized crime, a case study. Studies in Conflict \& Terrorism, 30(10), 901-920. doi: 10.1080/10576100701558620

Roth, M. P. \& Sever, M. (2008). Financial sources of the PKK. In Teymur, S., \& Smith, C. J. (Eds.). (2008). The PKK: a decades-old brutal marxist-leninist separatist terrorist organization (pp. 67-86). Turkish Institute for Security and Democracy.

Rudner, M. (2010). Hizbullah terrorism finance: fund-raising and money-laundering. Studies in Conflict \& Terrorism, 33(8), 700-715. doi: 10.1080/1057610X.2010.494169

Sahin, F. S. (2001). Case studies in terrorism-drug connection: the Kurdistan workers' party, the liberation tigers of Tamil Eelam, and the shining path (Doctoral Dissertation). University of North Texas, Texas.

Shanahan, T. (2016). The definition of terrorism. In Jackson, R. (Eds). Routledge handbook of critical terrorism studies (pp. 103-113). Boston: Routledge.

Sönmez, G. (2019). Factors behind the rise and fall of left-wing terrorism in Western Europe: the cases of rote armee fraktion and brigate rosse. Güvenlik Stratejileri Dergisi, 15(31), 469-496. doi: 10.17752/guvenlikstrtj.630849 
Sozer, M. A., \& Yilmaz, K. (2019). The PKK and its evolution in Britain (1984-present). Terrorism and Political Violence, 31(2), 185-203. doi: 10.1080/09546553.2016.1194269

TADOC-Department of Anti-Smuggling and Organized Crime. (1998). Drug connection of PKK terrorist organization. Ankara: TADOC Press

Tetik, Ü. \& Görücü, K. (2019). The PYD/PKK'S drug trafficking \& Turkey's war on narco-terrorism, Setav /Analysis, 52, 12-19. Erişim adresi: https://setav.org/en/assets/uploads/2019/06/52_PKK_Drug.pdf

The Ministry of Foreign Affairs of Turkey (2012). Turkey's effort against the drug problem. Erişim adresi: http://www.mfa.gov.tr/turkey_s-efforts-against-the-drug-problem.en.mfa.

The Ministry of Interior of Turkey (2017), Narko-terörizm ile mücadele uyusturucu ve PKK/KCK. Erişim adresi: https://www.icisleri.gov.tr/kurumlar/icisleri.gov.tr/IcSite/strateji/deneme/YAYINLAR/İÇERİK/narkoteror izm_web\%20icin.pdf.

The Ministry of Interior of Turkey, (2019). General directorate of police department of anti-narcotics crime drug report Turkey. Erişim adresi: http://www.narkotik.pol.tr/kurumlar/narkotik.pol.tr/TUBİM/Ulusal\%20Yayınlar/.

United Nations (1999). The 1999 United Nations international convention for the suppression of the financing of terrorism. Erişim adresi: https://www.un.org/law/cod/finterr.htm.

United States of America (2006). The national security strategy of the United States of America. Erişim adresi: https://www.comw.org/qdr/fulltext/nss2006.pdf.

United Nations (1988). the 1988 United Nations convention against illicit traffic in narcotic drugs and psychotropic substances. Erişim adresi: https://treaties.un.org/Pages/ViewDetails.aspx?chapter=6\&clang=_en\&mtdsg_no=VI$19 \&$ src $=$ IND.

Trapp, K. N. (2011). State Responsibility for International Terrorism. Oxford: Oxford University Press.

Turkish Anti-Terror Law (1991). Arişim adresi: https://www.ilo.org/dyn/natlex/docs/ELECTRONIC/22104/96348/F146542622/TUR22104.pdf

Turkish Criminal Code. (2004). Law no. 5237. Erişim adresi: https://www.legislationline.org/documents/action/popup/id/6872/preview

Unal, M. C. (2012). Counterterrorism in Turkey: policy choices and policy effects toward the Kurdistan workers' party (PKK). London: Routledge.

United Nations (1999). Security Council resolution 1566 (2004). [concerning threats to international peace and security caused by $\begin{array}{lllll}\text { terrorism], } & 8 & \text { October } & 2004, \mathrm{~S} / \mathrm{RES} / 1566 & \text { (2004). Erişim }\end{array}$ https://www.refworld.org/docid/42c39b6d4.html.

UNDOC (1998). Economic and social consequences of drug abuse and illicit trafficking. Erişim adresi: https://www.unodc.org/pdf/technical_series_1998-01-01_1.pdf

UNDOC (2020). Drug use and health consequences. Erişim adresi: https://wdr.unodc.org/wdr2020/en/drug-usehealth.html.

Victoroff, J.A, \& Kruglanski, A.W. (2009). Psychology of terrorism: the best writings about the mind of the terrorist. New York: Psychology Press Ltd.

Vision of Humanity (2020). The 2020 global terrorism index. Erişim adresi: https://www.visionofhumanity.org/wpcontent/uploads/2020/11/GTI-2020-web-1.pdf

Vittori, J. (2011). Terrorist financing and resourcing. Basingstoke: Springer.

Williams, P. (1998). Terrorism and organized crime: convergence, nexus or transformation?. FOA Report on Terrorism, Stockholm, Defence Research Establishment, 69-92.

Wilkinson, P. (2016). Political terrorism. London: Macmillan International Higher Education.

White, D. P. (2015). The PKK: coming down from the mountains. London: Zed Books Ltd.

\section{TÜRKÇE GENİŞ ÖZET}

Türkiye, Asya ile Avrupa arasında benzersiz bir coğrafi konuma sahiptir. Türkiye'nin eşsiz coğrafi konumu, Türkiye için bir avantaj olarak görünebilir; Ancak bu bazen güvenlik noktasında bir sorun da teşkil etmektedir. Türkiye'nin sınırları, siyasi açıdan istikrarsız ve az gelişmiş Orta Doğu ve Kafkasya ülkelerine ve de gelişmiş Avrupa ülkeleri arasında bir köprü görevi görür. Bu durum, Asya ile Avrupa arasında bir ülke olarak Türkiye'yi, ana ticaret ve taşımacılık güzergâhı olarak konumlandırmasını sağlamaktadır. Orta Amerika ülkesi olan Meksika ve Afrika ülkesi olan Fas da benzer sorunları yaşamaktadırlar. Ancak Türkiye'yi bu ülkelerden farklı kılan bir durum söz konusudur. Türkiye uzun yıllardır süregelen terör sorunu ile mücadele etmektedir. Özellikle de ayrılıkçı, etnik temelli hareket eden, Kürdistan İşçi Partisi (PKK) ile devam eden mücadele bu durumu daha da karmaşıklaştırmaktadır. Söz konusu örgüt, başlangıçta, kendi var oluş gerekçesi olan ideolojik yaklaşımı zamanla terk etmiş, etnik temelli bir ayrılıkçlık politikası izlemiştir. Geçen zaman içerisinde de diş devlet desteklerini kaybetmesiyle finans ihtiyacını bir başka yöntemle çözmek istemektedir. Burada, Türkiye'nin mevcut coğrafi konumu, organizasyonun bu durumdan yararlanmak istemesine neden olmuştur. Örgüt meşruiyet zemini oluşturduğu ideolojiden çok farklı hareket ederek yaşadışı işlere girişmektedir. Bu durum örgütün finansman ihtiyacı nedeniyle ortaya çıkmıştır. Bu özellikle onu destekleyen devlerin desteğini çektikten sonra görülüyor. Bu noktada çalışmanın araştırma konusu ortaya çıkmaktadır. Buradaki temel soru örgütün 
neden böyle bir yol izlediği ve sonucunda nasıl farklı bir yapıya evrildiğidir. Elbette, tüm terörist gruplar finansman sağlamak için farklı faaliyetler içinde bulunurlar. Bu noktada PKK'nın neden diğerlerinden farklı bir yol izlediğini açıklamak amacıyla örgütün ticaret ağı noktasındaki önemine değinilmiştir. Kimi örgütler farklı araçları kullanırlar. Bazıları kadın ya da organ kaçakçılı̆ını tercih ediyorken, bazıları da haraç yöntemini, kimisi de uyuşturucu kaçakçıllğı yöntemini tercih ediyor. PKK'nın en çok kullandığı yollardan biri ise uyuşturucu kaçakçıllğı̆dır. Türkiye'nin ulaşım rotasındaki konumu, örgütün Avrupa'da yer alan göçmenler ile ilişkisi organizasyonun bu noktada öne çıkmasını sağlamaktadır. Örgüt, Avrupa'da, özellikle, Almanya, Hollanda, Fransa, Belçika ve Birleşik Krallk'ta faaliyet göstermektedir. Bunun ana nedeni, bu ülkelerdeki Türk ve Kürt azınlık gruplarıdır. Bu azınlık grupları, hem ticaret için bir pazar hem de nakliye ve satış için hazır iş gücü anlamına gelir. Örgüt bu azınlık gruplarının varlı̆̆ı ve artan finansman ihtiyacı nedeniyle kendi kimliğinden uzaklaşarak varoluş nedenlerinden çok farklı bir yapıya kavuşmuştur. Bu yapı ise çalışmanın temel uğraklarından biri olan organize suç ve terörist gruplar arasındaki bağıntıdır. Bu bağıntı ile yasadışı uyuşturucu kaçakçılığ1 ve terörizm arasındaki etkileşim ortaya konulmaya çalışılacaktır. Çalışma uyuşturucu kaçakçılığının belirli grupların hedeflerine ulaşması için bir araç; diğerleri için hedefin kendisi olduğunu ileri sürmektedir. Bu amaç ve araçsallaşma PKK'da yekpare bir bütün olarak hedefin kendisine dönüştürmüştür. Bu noktada, çalışmanın temel önermesi olan terörist grupların farklı organize suç düzeyleri ile giriştikleri yapısal evrilmedir. Böylece finansman kaynaklarının ortadan kalması ile birlikte mali motivasyonları örgütlerin temel varoluş gerçekliği olmuştur. Buradan hareketle çalışmanın amacı, PKK örgütünün nasıl bir hibrit suç örgütü olduğunu ortaya çıkarmaktır. Pek çok akademisyen, farklı ancak iç içe geçmiş bu yapıların narko-terör örgütü olarak sınıflandırılmasını tercih ediyor. Bu çalışma kavramı biraz daha farklılaştırmak ve derinleştirmek istemektedir. Çalışma farklı bir açıdan yaklaşarak örgütlerin farklı yasadışı işleri aynı anda gerçekleştirdiklerini ortaya koyarak, artık örgütlerin sadece bir narco-terör örgütü değil artkk hibrit bir yapıya dönüştüklerini ortaya koymayı hedeflemektedir. Çalışmada da görülebileceği gibi, ticari motivasyonları genellikle politik motivasyondan daha ağır bastığı noktada değişim başlamaktadır. Bu metamorfoz organizasyonlarının tek bir suç türünden çıkarak farklı yasadışı işleri gerçekleştirdiğini ortaya koymaktadır. Bu nedenle, örgütlerin motivasyonları ne pahasına olursa olsun finansman sağlamakla ilgilidir. Meşruiyet gerekçelerini yok etme pahasına da olsa bu riskin alındığı görülmektedir. Bu noktadan itibaren iki başlı bir yapıları var: Bir tarafı terör örgütü, diğer tarafı uyuşturucu kaçakçısı (ya da organize suç örgütü). Örgüt, sınır aşan suçlar aracılı̆̆ıly melez bir örgüt olarak hareket etmeye başlar ve suç yeteneklerini sürekli olarak güçlendirir. Artık terör örgütü mü yoksa suç örgütü mü oldukları konusunda siyah beyaz bir ayrım yoktur. Tamamen gri alanda hareket eden bu yapılar; yasadış1 işlemlerini kolaylaştırmak için aldatıcı siyasi söylemlerini de sürdürmektedirler. Ancak görüldügü gibi artık örgüt terör örgütü olarak görülmemekte, tam tersine artık hem terör hem de bir suç örgütüdür. Bu da çalışmanın temel savı olan hibrit örgüt kavramının ortaya çıkış nedenini oluşturmaktadır. Elde edilen veriler dikkate alındığında, çalışmanın da konusu olan, bunlardan en bilineni PKK'dır. Suçun ciddiyeti ve Orta Doğu, Türkiye ve Avrupa'yı kapsayan suç ağı da dikkate alınırsa, örgüt BM metinlerine ve standartlarına göre uluslararası bir terör örgütüdür. Çalışmada örgütün uluslararası terör örgütleri listesinde yer aldığı dikkate alınmakta, bunun yanı sıra başta uyuşturucu kaçakçılığı olmak üzere işlediği diğer suçlarla mücadele için uluslararası dayanışma gerektiği vurgulanmaktadır. Söz konusu dayanışmanın sağlanması halinde hem toplumların sağlığı hem de güvenlik içinde yaşamalarının sağlanabileceği çalışmanın önerisidir. 